\title{
Students' Approaches to Learning the New B. Ed. Programme in Ghana: Evidence from Colleges of Education within Mampong Municipality
}

\author{
Moses Azerimi Azewara ${ }^{1^{*}}$, , Emma Poku Agyeman ${ }^{1}$, Joseph Dawson-Ahmoah $^{1}$, Aaron Adusei $^{1}$, Eric \\ Twum-Ampofo ${ }^{2}$
}

${ }^{1}$ Department of Education Studies, St. Monica's College of Education P.O. Box 250, Mampong-Ashanti, Ghana

${ }^{2}$ Department of Interdisciplinary Studies, Appiah-Minka University of Skills Training and Entrepreneurial Development, MampongAshanti, Ghana

Email: azewaramoses@gmail.com

Received: 8 May 2021; Revised: 6 August 2021; Accepted: 6 August 2021

\begin{abstract}
This paper explores the use of surface and deep learning strategies of students in two Colleges of Education within Mampong Municipality: St. Monica's College (Single-Sex College-Female) and Mampong Technical College (Single-Sex College-Male) who were enrolled to read a Four-Year Bachelor of Education programme. Drawing on Biggs et al.'s Revised Study Questionnaire (2001), the study investigates whether student-teachers adopt a predominantly surface or deep learning approach to their studies for the New B. Ed. programme introduced into the Colleges of Education. From February to April 2021, we employed a quantitative cross-sectional design. A selfadministered questionnaire was used to collect data from 332 participants (level 200 and 300) who were enrolled to study the four-year B. Ed. programme which was introduced in 2018. One-way analysis of variance (ANOVA) and t-tests were used to examine participants' age, sex and level of study in correlation with their learning approaches (Deep or Surface). A significant difference in the Deep learning approach was found between males and females in both schools $(p=0.47)$. However, there was no significant difference between age, level and learning approach. Their responses were analysed using descriptive statistics. Findings suggest that student-teachers appear to adopt deep learning strategies in their studies at Colleges of Education and that this approach to learning was used regardless of the discipline in which they were enrolled.
\end{abstract}

Keywords: students' approach, learning, colleges of education, Ashanti

\section{Introduction}

The approaches to students' learning have been extensively studied over decades which is not a new conversation (Biggs, 1970, 1978, 1987; Entwistle, 1970; Marton \& Saljo, 1976; Dansereau, 1978; Gardener, 1992; Kolb, 1984, 2012; Case \& Marshall, 2009; Cano \& Berbén, 2009). The term "learning approaches" is used to connote what learners do when involving in the learning process, and their deep passion to engage in a particular way of learning tasks (Diseth, 2003; Uiboleht et al., 2018). According to Biggs (1987) and Diseth (2003), approaches to learning are the preferred manner in which students deal with learning tasks. Students' approaches to learning may either promote or hinder their

Copyright (C2021 Moses Azerimi Azewara, et al.

DOI: https://doi.org/10.37256/ser.222021914

This is an open-access article distributed under a CC BY license

(Creative Commons Attribution 4.0 International License)

https://creativecommons.org/licenses/by/4.0/ 
academic progress (Brown et al., 2015; Richardson et al., 2012; Lublin, 2003). Several studies have been conducted over the years to determine the learning approaches that specific groups of students adopt, and the factors in the various groups that motivate their learning approaches (Chonkar et al., 2018; Beattie, 1997). The definition of learning approaches involved two main elements: the deep learning approach (DLA) and the surface learning approach (SLA). A consistent finding is that learning is an endless journey and that one stops learning when she or he is dead and that approaches to learning are determined by motivational factors (intrinsic and extrinsic) (Beattie, 1997; Leiva-Brondo et al., 2020). Also, the learning environment, the content, the duration of the programme and the teaching strategies employed by teachers can influence students to adopt a particular learning approach. The process of learning can be categorized into three variables: presage, process and product (PPP). Biggs et al. (2001) posits that these variables are highly interrelated system which form a synergy for better comprehension of the process of learning. The presage variables (PV) are the prior experiences learners bring into the learning environment which is being propelled by both intrinsic and extrinsic factors. Intrinsic factors are the personal desires or deep passion learners naturally exhibit which are demonstrable by visible attributes in the learning outcome such as committed or not, dedicated or undedicated among others. Extrinsic factors, on the other hand, refer to the learning environment in which the student finds him/ herself in and the factors that may influence the learner's decisions are the learning load, teaching methods and forms of assessment (Beattie et al., 1997; Alkadhi, 2008; Alt \& Boniel-Nissim, 2018). Several pieces of research have indicated that the learning environment alone can compel a student to adopt a Deep Learning Approach (DLA) or Surface Learning Approach SLA (Bonsaksen et al., 2017; Desierto et al., 2018; Ellis \& Bliuc, 2019; Uiboleht et al., 2018; Beattie et al., 1997; Biggs et al., 2001; Ames et al., 1992; Ramsden et al., 1997, 2003, 2008; Alom et al., 2018; Delgado et al., 2018).

Learning as a process may be influenced by motivational factors (intrinsic or extrinsic or both) (Beattie et al., 1997; Ryan et al., 2020; Lucchetti \& Lucchetti, 2018). With DLA, students are engaged in meaningful learning where learners can think critically and independently and interpret information that has a lasting impact on them while SLA seeks to merely recall basic facts and the main aim is for learners to excel in a test or an examination (Hyytinen et al., 2018; Hamilton \& O’Dwyer, 2018; Lindblom-Ylänne et al., 2019; Rolleston et al., 2019; Stokes et al., 2020). DLAs are more focused on knowledge transformation whereas SLA mainly on knowledge reproduction. With the surface approach to learning, students use strategies such as memorisation to finish their academic tasks, pass their studies, and are thus "focused on reproducing" knowledge (University of Oxford, 2017).

The fundamental distinction is that the SLA often relies on performing well in assessment. This does not lead to the proper development of learners' skills and competencies in the content of the subject being taught; the prime focus is just excelling in an examination or a test. On the other hand, in DLA, students delve deep into the content being taught and they are able to interpret the material presented to them to make their own meanings and judgment. This kind of in-depth analysis of the subject matter by students is a clear manifestation of their deep passion and burning desire to obtain knowledge to solve personal and societal problems. With DLA, performance in assessments is considered a secondary matter (Mensah et al., 2019; Nieminen et al., 2019; Peng et al., 2019; Owusu et al., 2019; University of Oxford, 2017; Mosca et al., 2015; Byrne et al., 2010; Biggs et al., 2001; Biggs \& Tang, 2007; Ramsden et al., 1997, 2003, 2008; Entwistle, 2000, 2003). Student Approach to Learning (SAL) plays a key role; therefore, teaching should be seen as the process of providing guidance and direction to learners.

The New Curriculum (four-year Bachelor of Education) programme was the first of its kind introduced to the Colleges of Education in Ghana in 2018 when all Colleges of Education that were previously running certificates and diploma in education programmes have been phased out. The main focus of the New Curriculum is to train professional teachers with the needed pedagogical content knowledge and skills for them to be able to create and share knowledge with young children in primary and junior high schools in Ghana. The New B. Ed. centered on good teaching which influences students to take a deep approach, while poor teaching in the widest sense can pressure students to take a surface approach. These views and observations are in consonance with modern preferences for learner-led and peerassistive pedagogical strategies (University of Cape Coast Training Manual, 2018). Students' teachers have been empowered to think critically and solve problems independently while lecturers play a facilitating role. With the New B. Ed. programme, the traditional methods of teaching and assessment have been discarded, because they are no longer helpful in training teachers in the $21^{\text {st }}$ century. This study was carried out for course lecturers to assess how learners approach their studies in the New B. Ed. programme. The study will serve as a guide to course lecturers, coordinators 
and professional manual writers to appreciate how students are coping with the new content, workload and the learning environment and to ascertain whether course lecturers in the Colleges of Education are applying the appropriate pedagogies in teaching as well as students applying the appropriate learning strategies in their studies.

Also, an in-depth analysis will be shed on the learning approaches that may inform fair judgment on the appropriateness of the B. Ed. programme structure, content and pedagogical strategies employed by course lecturers in the Colleges of Education in Ghana.

\section{Objective of the study}

The main objective of the study was to examine which learning approaches (DLA or SLA) were adopted by second-year and third-year students in the new B. Ed. Programme in the Colleges of Education in Ghana.

\section{Hypothesis}

Ho: There will be no significant difference between sex (male and female) and learning approaches.

Ho: There will be no significant difference between level of study and learning approaches.

Ho: There will be no significant difference between age and learning approaches.

\section{Methods and materials}

This study employed the quantitative cross-sectional research design. The study was conducted at St. Monica's College of Education (Single-Sex College female) and Mampong Technical College of Education (Single-Sex College male) in Mampong Municipality in Ashanti Region, Ghana. The participants for the study were regular students enrolled in the four-year Bachelor of Education programme full-time. The four-year Bachelor of Education programme was the first of its kind being introduced in the Colleges of Education in Ghana in 2018 to replace the then Diploma in Basic Education (DBE) programme. The first batch of the B. Ed. programme (current level 300 and the second batch, level 200) was invited to participate in the study. The participants who were willing to participate in the survey were included after they had agreed to sign the consent form. Those who were not willing and did not sign the consent form were excluded from the study. This study used the ROASOAFT (https://www.Calculator.net/) sampling calculator with a 95\% confidence level resulting in 332 participants from both schools (Mampong Technical College of Education and St. Monica's College of Education register). The researchers employed the probability sampling approach (Method of Chance) to choose 332 respondents. The researchers assigned a unique identity to every learner from level 200 to 300 in both schools. The numbers assigned to each participant were derived from the registry with unique identities generated from an automatic random number programme. The researchers organised an orientation programme on the purpose of the research, benefits, risks and anonymity of the participants were discussed during break times in both schools before the actual commencement of the research work. Again, participants were given the opportunity to ask questions for clarification and informed consent forms were signed by each participant. The prepared questionnaires were self-administered to participants to collect the data. Data collection commenced from February to April, 2021 when all schools in Ghana have resumed after one year lockdown due to the Covid-19 outbreak. The questionnaires were administered by the researchers in person to each participant during break time. The study used Bigg's Revised two-factor Process Study Questionnaire (R-SPQ-2F) (Biggs et al., 2001; Pérez-de-Castro, 2020; Ali \& Rizvi, 2019). The items on the Likert scale which were 5 under Biggs' R-SPQ-2F were modified a bit to suit the context of this study to be four main items or options (Strongly Agree $=4$, Agree $=3$, Disagree $=2 \&$ Strongly Disagree $=1$ ). The questionnaire was specifically designed as a sensitive tool to identify students' approaches to learning. The questionnaire also contains a sub-scale that makes room for data interpretation in order to make identification of factors that influence students learning approach. The motive subscale is adopted to indicate the intrinsic factors that entice students to choose either a DLA or an SLA, and the strategy subscale to identify the extrinsic factors of the learning environment that motivate students in the teaching and learning process (Biggs et al., 2001). This questionnaire assesses deep and surface 
approaches using 20 items. The questionnaires were pilot-tested at St. Monica's College of Education by three experts (an assessment officer, a subject-leader in Measurement and Evaluation, and an Educational Psychology expert all in Education Department). The three experts have all agreed that the 20 items were suitable and deemed applicable for the research problem. Twenty study items were tried out with twenty students to ascertain the validness of the research tool. The reliability test yielded an alpha coefficient of 0.85 . A one-way analysis of variance (ANOVA) was used to test the differences among participants' age groups and learning approaches (SLA or DLA). Again, the researchers employed an independent t-test to ascertain if there were differences between participants' sex and learning approaches and also levels (Level 200 and Level 300) and learning approaches. All factual investigations were performed utilising Statistical Package for the Social Sciences version 25 (SPSS V.25). All values were set to a 0.05 level of significance.

\section{Results}

Out of the 332 respondents, the majority (244) constituting 73.5 percent were females while 26.5 percent were males. In terms of the gender, females were more than males. This is also illustrated in the Figure 1 below.

Table 1. Sex of respondents

\begin{tabular}{ccc}
\hline Sex & Frequency & Percentage (\%) \\
\hline Male & 88 & 26.5 \\
Female & 244 & 73.5 \\
Total & 332 & 100.0 \\
\hline
\end{tabular}

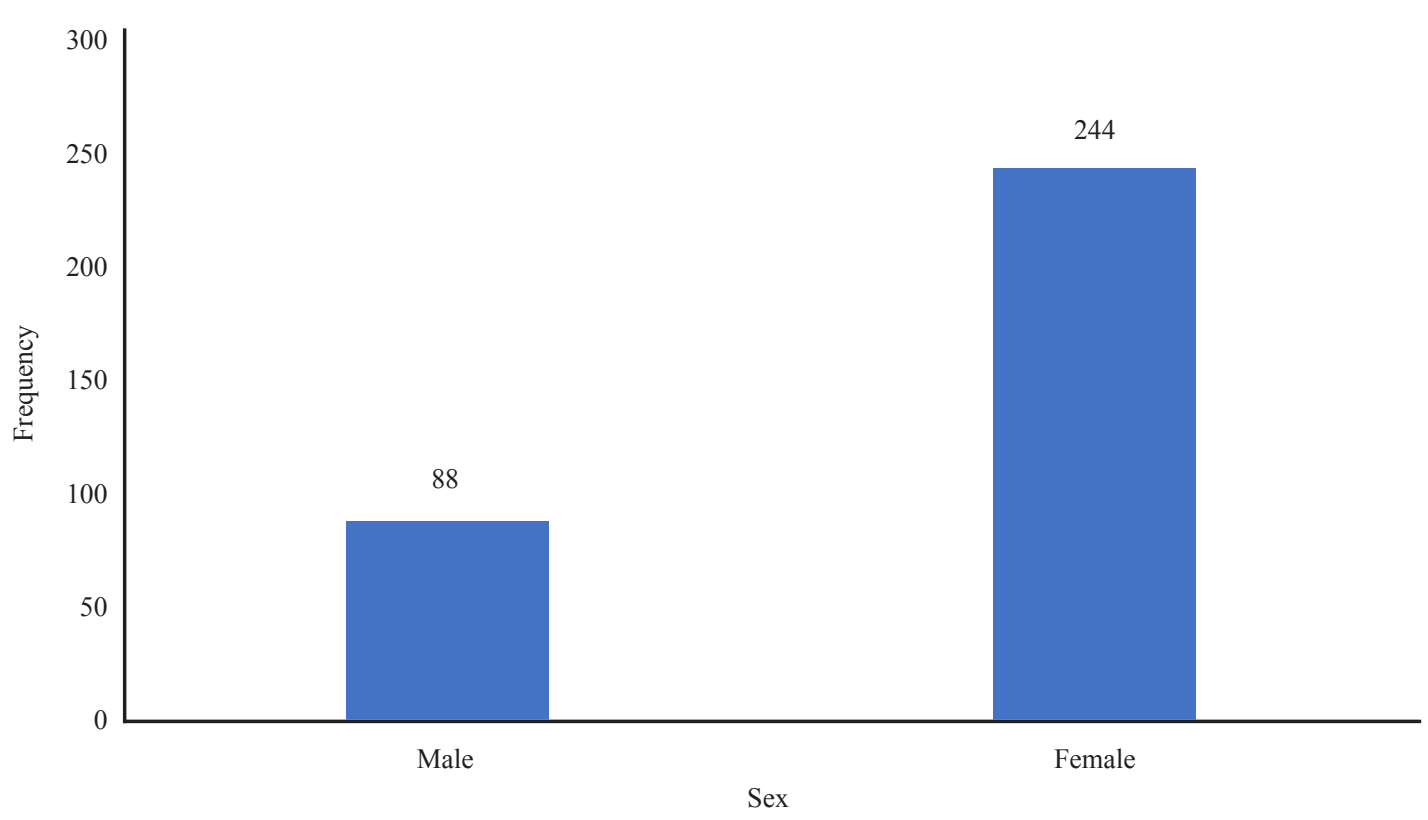

Figure 1. Sex of respondents

The majority of the participants (282) representing 85.0\% aged 20-25 while 12 representing 3.6\% was below 20 years took part in the study. This is further illustrated in the Figure 2 below. 
Table 2. Age of respondents

\begin{tabular}{ccc}
\hline Age & Frequency & Percentage (\%) \\
\hline below 20 & 12 & 3.6 \\
$20-25$ & 282 & 85.0 \\
above 25 & 38 & 11.4 \\
Total & 332 & 100.0 \\
\hline
\end{tabular}

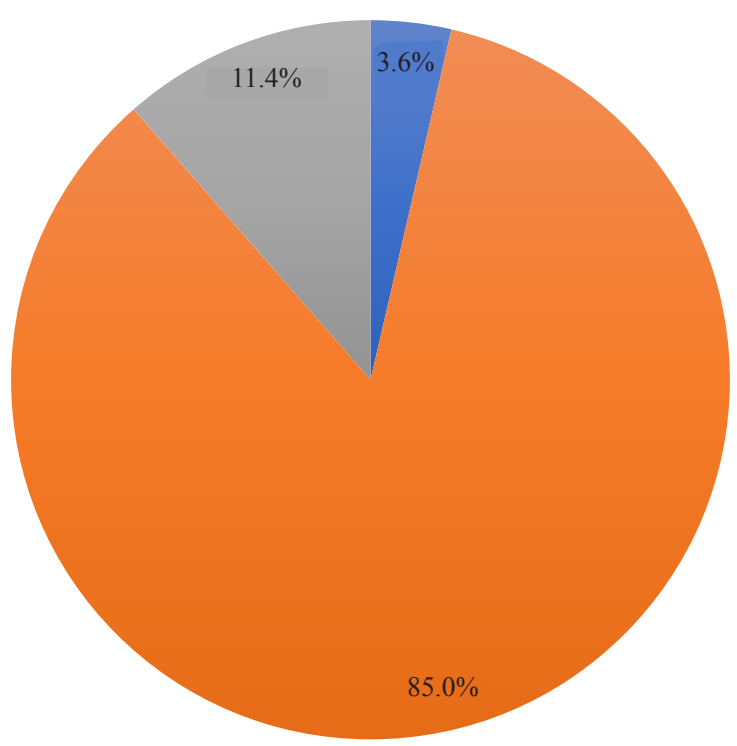

Below $20 \square$ 20-25 $\square$ Above 25

Figure 2. Age of respondents

Out of the 332 participants, level 200 students (192) representing 57.8\% participated in the study while level 300 (140) constituting $42.2 \%$ took part in the study. This is shown in figure 3 below:

Table 3. Level of respondents

\begin{tabular}{ccc}
\hline Level & Frequency & Percentage (\%) \\
\hline 200 & 192 & 57.8 \\
300 & 140 & 42.2 \\
Total & 332 & 100.0 \\
\hline
\end{tabular}

Table 4 presents the findings of the single-direction examination of fluctuation (ANOVA) and t-test examining differences in participants' deep and surface learning scores and age groups. The single-direction ANOVA uncovered that there were no genuinely huge contrasts across age groups and learning approaches of students in both schools.

A significant difference was noted between sex (male and female) and the learning approaches of participants when 
the independent t-test was employed.

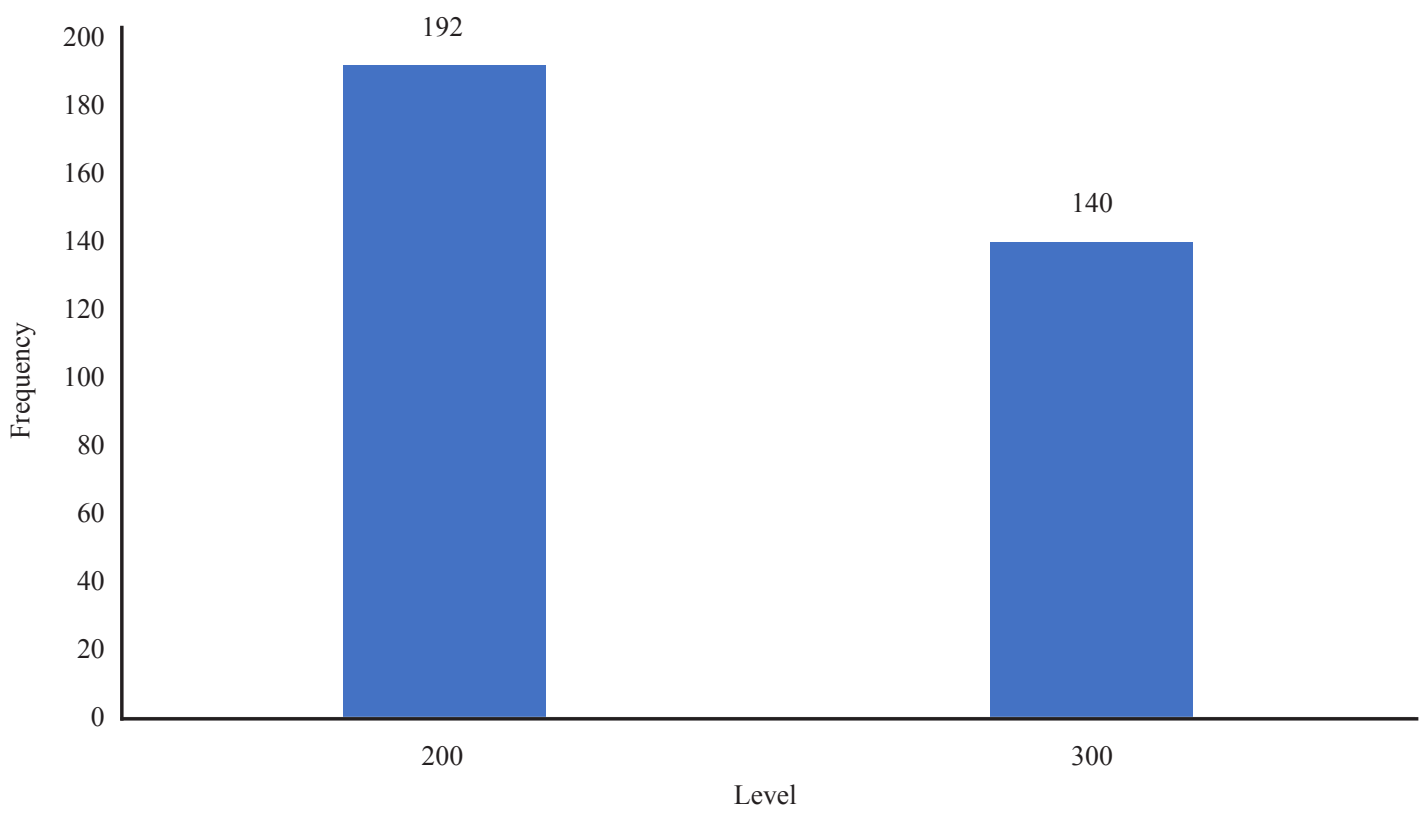

Figure 3. Level of respondents

Table 4. Difference between learning approach scores and respondents' Characteristics $(\mathrm{N}=332)$

\begin{tabular}{|c|c|c|c|c|c|c|c|}
\hline Variable & Frequency & Mean & SD & Test value & $\mathrm{Df}$ & $\mathrm{p}$ & Interpretation \\
\hline \multicolumn{8}{|l|}{ Age } \\
\hline Below 20 & $12(3.6)$ & 2.942 & 0.174 & $\mathrm{f}(2.879)$ & 2 & 0.058 & Not significant \\
\hline $20-25$ & $282(85.0)$ & 2.891 & 0.388 & & & & \\
\hline Above 25 & $38(11.4)$ & 2.740 & 0.344 & & & & \\
\hline \multicolumn{8}{|l|}{ Sex } \\
\hline Male & $88(26.5)$ & 2.944 & 0.473 & $\mathrm{t}(1.997)$ & 330 & 0.047 & Significant \\
\hline Female & $244(73.5)$ & 2.850 & 0.338 & & & & \\
\hline \multicolumn{8}{|l|}{ Level } \\
\hline 200 & $192(57.8)$ & 2.938 & 0.399 & $\mathrm{t}(3.585)$ & 330 & 0.501 & Not significant \\
\hline 300 & $140(42.2)$ & 2.789 & 0.334 & & & & \\
\hline
\end{tabular}

Field survey, (2021)

Lastly, the independent t-test was again tested to explore participants' levels (level 200 and level 300) and learning approaches. It was revealed that there were no statistically significant differences between levels and learning approaches of students in both schools.

\subsection{Discussion}

The findings of this study have shown that Colleges of Education students who were enrolled to study a four-year 
Bachelor of Education programme for the first time used both deep and surface learning approaches. The results of this study on the learning strategies used by College students appear to both support and contradict existing literature on deep and surface learning approaches. The findings support Wang's (2013) finding that the learning approach adopted by students does not depend on the discipline in which they are studying. On the other hand, the findings from this study contradict other research which has found that undergraduate students tend to adopt a surface approach to learning (Brown et al., 2015; Turner \& Baskerville, 2013; Donnison \& Penn-Edwards, 2012; Laird et al., 2008; Entwistle \& Peterson, 2004). Thus, it seems amazing as to why the majority of students, who are undergraduates, demonstrate knowledge of and belief in their use of strategies for a deep learning approach in the face of literature that would suggest otherwise. The majority of the students adopted the deep learning approaches rather than the surface approach. The students engaged in deep learning because of the passion they possess in understanding the courses they study, teaching strategies adopted by course lecturers and how they translate the knowledge to solve personal and societal problems. Teaching must involve reflective decision making which is developed through deep learning so they can create and share knowledge with their learners when they complete their studies. Several studies have been reported where few differences in learning approaches between undergraduates and other specialism like nursing education. Studies revealed that age played a crucial role in participants' choice of a particular learning approach (Tove et al., 2018).

The investigation uncovered a critical distinction in the participants' sex (male/female) and learning approaches. Some studies have found that females were more likely than males to engage in surface learning than their male counterparts (Adela et al., 2020; Mahmud \& Nur, 2019). Alluding to sex, female understudies scored fundamentally higher in their inclination towards all learning styles than their male friends which is the reason the primary theory by which it was expected that there was no huge distinction in learning style inclination dependent on sex was upheld. We, therefore, rejected the null hypothesis (1). These findings are in consonance with research by Lai (2001) who found that male and female students differ significantly in their approach to learning. While others studies claimed that sex and how students study have no particular pattern (Cetin, 2016), other researchers saw a significant difference between age and learning approaches. These authors highlighted that older learners tilt towards a deep learning approach than younger students because the older students are more superior in exhibiting their experiences which is important to meet their intellectual advancement (Yonker, 2011; Alsayed et al., 2021). However, in other studies, the age and learning approach played no important contrast in students learning (Gerritsen-van Leeuwenkamp et al., 2019). This study revealed that students' age has no influence over their learning approaches as the majority of them appeared to adopt a deep learning approach. Similarly, Venkatesan's (2015) study revealed a difference in students' preferred learning styles that changes with time. With Hypotheses (2) and (3) we do not reject the null hypotheses because there was no statistically significant relationship between levels and learning approaches and age and learning approaches. Students may tend to change their approach to learning as they climb the academic ladder because they will like to be autonomous and self-directed in whatever they do in school and relate it to the real world.

\subsection{Conclusion}

College students use the DLA in their studies though a handful of them also use the Surface approach. Both learning approaches are important and valuable in Teacher Education. There was no statistically significant difference between age and learning approach, levels (level 200 and level 300) and learning approach. However, significant differences existed between sex (male and female) and the learning approach. Colleges authority should create a conducive environment for students to develop better the DLA which involves in-depth analysis, problem-solving and critical thinking.

\subsection{Policy implications}

Course lecturers in the Colleges of Education in Ghana must all embrace and shift their mode of instruction where lecturers were considered as the custodian of knowledge to being facilitators of students learning. When lecturers employ student-centered approaches such as cooperative learning, project method, fishbowl, jigsaw puzzles, experiential learning strategies among others, will go a long way to motivate student-teachers to adopt a deep learning approach. Also, the mode of assessment of students should be based on the learning needs of students. The focus of assessment (assessment for, assessment of and assessment as) should be rigidly enforced to ensure that student-teachers grab the 
needed pedagogical skills and competencies as $21^{\text {st }}$ century teachers. More so, while the educational success of the students can be attributed to the facilitator's rich experiences and competencies, the need to integrate a deep approach in diverse characteristics of students should be considered and supported. The success in achieving the New B. Ed. programme goals heavily relied on the rapport among lecturer-student and student-student relationships. Finally, the findings from this study will be forwarded to the University of Cape Coast, College of Education Studies for proper review of the courses offered at the Colleges of Education and so they can retrain College lecturers on student-centered pedagogies for them to encourage student-teachers to adopt deep learning approaches.

\section{References}

Adela, M., Edda, P., \& Senad, B. (2020). The relationship between learning styles, GPA, school level and gender. European Researcher, 11(1), 51-60. https://doi.org/10.13187/er.2020.1.51

Alkadhi, S. (2008). Learning theory: adult education: andragogy. Unpublished manuscript. California State University, Monterey Bay, California, CA.

Alom, M. Z., Taha, T. M., Yakopcic, C., Westberg, S., Sidike, P., Nasrin, M. S., \& Asari, V. K. (2018). The history began from alexnet: A comprehensive survey on deep learning approaches. Computer Vision and Pattern Recognition. arXiv: 1803.01164.30-39.

Alsayed, S., Alshammari, F., Pasay-An, E., \& Dator, W. L. (2021). Investigating the learning approaches of students in nursing education. Journal of Taibah University Medical Sciences, 16(1), 43-49. https://doi.org/10.1016/ j.jtumed.2020.10.008

Alt, D., \& Boniel-Nissim, M. (2018). Links between adolescents' deep and surface learning approaches, problematic Internet use, and fear of missing out (FoMO). Internet Interventions, 13, 30-39.

Ames, C. (1992). Classrooms: Goals, structures, and student motivation. Journal of Educational Psychology, 84(3), 261-271. https://doi.org/10.1037/0022-0663.84.3.261

Ali, K. F. M., \& Rizvi, K. F. (2019). Comparing the learning approaches using Biggs revised study process questionnaire (R-SPQ-2F) among dental undergraduates. Journal of The Pakistan Dental Association, 28(2), 68-73. https://doi. org/10.25301/JPDA.282.68

Beattie, V., Collins B., \& McInnes, B. (1997). Deep and surface learning: a simple or simplistic dichotomy? Accounting Education, 6(1), 1-12. https://doi.org/10.1080/096392897331587

Biggs, J. B. (1970). Faculty patterns in study behaviour. Australian journal of Psychology, 22(2), 161-174. https://doi. org/10.1080/00049537008254570

Biggs, J. B. (1978). Individual and group differences in study processes. British Journal of Educational Psychology, 48(3), 266-279. https://doi.org/10.1111/j.2044-8279.1978.tb03013.x

Biggs, J. B. (1987). Student approaches to learning and studying. Melbourne: Australian Council for Educational Research.

Biggs, J., \& Tang, C. (2007). Teaching for quality learning at university (3rd ed.). Berkshire, UK: Oxford University Press. https://www.sarahnilsson.org/app/download/965826150/2_49657968-Teaching-for-Quality-Learning-atUniversity.pdf

Biggs, J., Kember, D., \& Leung, D. Y. (2001). The revised two-factor study process questionnaire: R-SPQ-2F. British Journal of Educational Psychology, 71(1), 133-149. https://doi.org/10.1348/000709901158433

Bonsaksen, T., Brown, T., Lim, H. B., \& Fong, K. (2017). Approaches to studying predict academic performance in undergraduate occupational therapy students: a cross-cultural study. BMC Medical Education, 17(1), 1-9. https:// doi.org/10.1186/s12909-017-0914-3

Brown, S., White, S., Wakeling, L., \& Naiker, M. (2015). Approaches and study skills inventory for students (ASSIST) in an introductory course in chemistry. Journal of University Teaching and Learning Practice, 12(3), 1-12. http:// ro.uow.edu.au/jutlp/vol12/iss3/6

Byrne, M., Finlayson, O., Flood, B., Lyons, O., \& Willis, P. (2010). A comparison of the learning approaches of accounting and science students at an Irish university. Journal of Further and Higher Education, 34(3), 369-383. https://doi.org/10.1080/0309877X.2010.484055

Cano, F., \& Berbén, A. B. G. (2009). University students' achievement goals and approaches to learning in mathematics. British Journal of Educational Psychology, 79(1), 131-153. https://doi.org/10.1348/000709908X314928

Case, J. M., \& Marshall, D. (2009). Approaches to learning. The Routledge international handbook of higher education (pp. 9-22). Routledge. https://www.taylorfrancis.com/chapters/edit/10.4324/9780203882221-2/approaches- 
learning-jennifer-case-delia-marshall?context=ubx\&refId=1231834e-1575-4a90-b672-8cd49d904bce

Cetin, B. (2016). Approaches to learning and age in predicting college students' academic achievement. Journal of College Teaching \& Learning (TLC), 13(1), 21-28. https://doi.org/10.19030/tlc.v13i1.9568

Chonkar, S. P., Ha, T. C., Chu, S. S. H., Ng, A. X., Lim, M. L. S., Ee, T. X., Ng, M. J., \& Tan, K. H. (2018). The predominant learning approaches of medical students. BMC Medical Education, 18(1), 1-8. https://link.springer. com/article/10.1186/s12909-018-1122-5

Dansereau, D. F. (1978). The development of a learning strategies curriculum. In H. F. O’Neill, Jr. (Ed.), Learning strategies (pp. 1-29). New York: Academic Press. https://doi.org/10.1016/B978-0-12-526650-5.50006-X

Delgado, Á. H. D. A., Almeida, J. P. R., Mendes, L. S. B., Oliveira, I. N. D., Ezequiel, O. D. S., Lucchetti, A. L. G., \& Lucchetti, G. (2018). Are surface and deep learning approaches associated with study patterns and choices among medical students? A cross-sectional study. Sao Paulo Medical Journal, 136(5), 414-420.

Desierto, A., De Maio, C., O’Rourke, J., \& Sharp, S. (2018). Deep or Surface? The learning approaches of enabling students in an Australian public university. STARS Conference. https://ro.ecu.edu.au/ecuworkspost2013/5226/

Diseth, Å. (2003). Personality and approaches to learning as predictors of academic achievement. European Journal of Personality, 17(2), 143-155. https://doi.org/10.1002/per.469

Donnison, S., \& Penn-Edwards, S. (2012). Focusing on first year assessment: Surface or deep approaches to learning? International Journal of the First Year in Higher Education, 3(2), 9-20. https://doi.org/10.5204/intjfyhe.v3i2.127

Ellis, R. A., \& Bliuc, A. M. (2019). Exploring new elements of the student approaches to learning framework: The role of online learning technologies in student learning. Active Learning in Higher Education, 20(1), 11-24. https://doi. org/10.1177/1469787417721384

Entwistle, N. (2000). Promoting deep learning through teaching and assessment. Assessment to Promote Deep Learning: Insights from AAHF's 2000 and 1999 Assessment Conferences (pp. 9-20). University of Leicester. https://scholar. google.com/scholar_url?url=https://www.researchgate.net/profile/Noel_Entwistle/publication/285909232_ Promoting_deep_learning_through_teaching_and_assessment/links/568d3b9208aef987e565e131/Promoting-deeplearning-through-teaching-and-assessment\&hl=zh-CN\&sa=X\&ei=5h0SYcO1F9CAywTGk5W4BQ\&scisig=AAG Bfm0_izwzWejYZYdV8wkIFkYw9h9PIA\&oi=scholarr

Entwistle, N. (2003). Promoting deep learning through teaching and assessment: conceptual frameworks and educational contexts. TLRP Conference, Leicester.

Entwistle, N. J., \& Entwistle, D. (1970). The relationships between personality, study methods and academic performance. British Journal of Educational Psychology, 40(2), 132-143. https://doi.org/10.1111/j.2044-8279.1970. tb02113.x

Entwistle, N., \& Peterson, E. (2004). Learning styles and approaches to studying. Encyclopedia of Applied Psychology, 2 , 537-542. https://www.researchgate.net/profile/Elizabeth-Peterson-5/publication/285909283_Learning_Styles_and_ Approaches_to_Studying/links/5af5f3bf0f7e9b026bcee09c/Learning-Styles-and-Approaches-to-Studying.pdf

Gardner, H. (1992). Multiple intelligences. Minnesota Center for Arts Education.

Gerritsen-van Leeuwenkamp, K. J., Joosten-ten Brinke, D., \& Kester, L. (2019). Students' perceptions of assessment quality related to their learning approaches and learning outcomes. Studies in Educational Evaluation, 63, 72-82. https://doi.org/10.1016/j.stueduc.2019.07.005

Hamilton, M., \& O'Dwyer, A. (2018). Exploring student learning approaches on an initial teacher education programme: A comparison of mature learners and direct entry third-level students. Teaching and Teacher Education, 71, 251261.

Hyytinen, H., Toom, A., \& Postareff, L. (2018). Unraveling the complex relationship in critical thinking, approaches to learning and self-efficacy beliefs among first-year educational science students. Learning and Individual Differences, 67, 132-142. https://doi.org/10.1016/j.lindif.2018.08.004

Kolb, D. A. (1984). Experiential learning: experience as the source of learning and development. Englewood Cliffs, NJ: Prentice Hall. https://www.researchgate.net/publication/235701029_Experiential_Learning_Experience_As_The_ Source_Of_Learning_And_Development

Kolb, A. Y., \& Kolb, D. A. (2012). Experiential learning theory. In N. M. Seel (Ed.), Encyclopedia of the Sciences of Learning (pp. 1215-1219). Springer, Boston, MA. https://doi.org/10.1007/978-1-4419-1428-6_227

Lai, S. H. (2001). Student perceptions regarding needs for communication based English instruction in a selected University in Southern Taiwan. Doctoral Dissertation at the University of South Dakota. https://www.proquest. com/openview/5136c8033d99446076bc7f35021e3e3a/1?pq-origsite=gscholar\&cbl=18750\&diss=y

Laird, T. F. N., Shoup, R., Kuh, G. D., \& Schwarz, M. J. (2008). The effects of discipline on deep approaches to student learning and college outcomes. Research in Higher Education, 49(6), 469-494. https://ink.springer.com/ article/10.1007/s11162-008-9088-5 
Leiva-Brondo, M., Cebolla-Cornejo, J., Peiró, R., Andrés-Colas, N., Esteras, C., Ferriol, M., Farinós, H. B. M., Niclós, M. J. T. D. J. D., \& Pérez-de-Castro, A. (2020). Study approaches of life science students using the revised two-factor study process questionnaire (R-SPQ-2F). Education Sciences, 10(7), 173. https://doi.org/10.3390/educsci10070173

Lindblom-Ylänne, S., Parpala, A., \& Postareff, L. (2019). What constitutes the surface approach to learning in the light of new empirical evidence? Studies in Higher Education, 44(12), 2183-2195. https://doi.org/10.1080/03075079.20 18.1482267

Lublin, J. (2003). Deep, surface and strategic approaches to learning. Belfield: Centre for Teaching and Learning, University College Dublin. https://studylib.net/doc/18290095/deep--surface-and-strategic-approaches-to-learning

Lucchetti, A. L. G., \& Lucchetti, G. (2018). Are surface and deep learning approaches associated with study patterns and choices among medical students? A cross-sectional study. Sao Paulo Medical Journal, 136(5), 414-420. https:// doi.org/10.1590/1516-3180.2018.0200060818

Richardson, M., Abraham, C., \& Bond, R. (2012). Psychological correlates of university students' academic performance: A systematic review and meta-analysis. Psychol Bull, 138(2), 353-387. https://doi.org/10.1037/ a0026838

Marton, F., \& Säljö, R. (1976). On qualitative differences in learning: I-Outcome and process. British journal of educational psychology, 46(1), 4-11. https://doi.org/10.1111/j.2044-8279.1976.tb02980.x

Mahmud, M., \& Nur, S. (2019). Exploring students' learning strategies and gender differences in english language teaching. TEFLIN Journal, 21(2), 172-184.

Mensah, K. T., Argyriadis, A., \& Arkoh, E. A. (2019). Student learning approaches in a Ghanaian medical school. Education in Medicine Journal, 11(3), 45-53. https://doi.org/10.21315/

Mosca, C., Makkink, A., \& Stein, C. (2015). Learning approaches used by students in an undergraduate emergency medical care programme. African Journal of Health Professions Education, 7(1), 55-57. https://doi.org/10.7196/ AJHPE.393

Nieminen, J. H., Asikainen, H., \& Rämö, J. (2019). Promoting deep approach to learning and self-efficacy by changing the purpose of self-assessment: A comparison of summative and formative models. Studies in Higher Education, 46(7), 1297-1311. https://doi.org/10.1080/03075079.2019.1688282

Owusu, G. M. Y., Kwakye, T. O., Bekoe, R. A., \& Welbeck, E. (2019). Approaches to learning of accounting students in Ghana. UCP Management Review (UCPMR), 3(1), 69-93. https://www.researchgate.net/profile/ Godfred-Owusu-3/publication/338037939_Approaches_to_Learning_of_Accounting_Students_in_Ghana/ links/5dfb47d44585159aa487ff24/Approaches-to-Learning-of-Āccounting-Students-in-Ghana.pdf

Peng, M. Y. P., \& Chen, C. C. (2019). The effect of instructor's learning modes on deep approach to student learning and learning outcomes. Educational Sciences: Theory \& Practice, 19(3), 65-85. https://eric.ed.gov/?id=EJ1232941

Pérez-de-Castro, A. (2020). Study approaches of life science students using the revised two-factor study process questionnaire (R-SPQ-2F). Education Sciences, 10(7), 173. https://doi.org/10.3390/educsci10070173

Ramsden, P. (1997). The context of learning in academic departments. The experience of learning, 2, 198-216.

Ramsden, P. (2003). Learning to teach in higher education. London: Routledge. http://utlc.uum.edu.my/images/bahan/ Learning_to_Teach_in_Higher_Education_Ramsdens_book1992.pdf

Ramsden, P. (2008). The future of higher education teaching and the student experience. The Higher Education Academy. https://www.advance-he.ac.uk/knowledge-hub/future-higher-education-teaching-and-student-experience

Rolleston, C., Schendel, R., \& Grijalva Espinosa, A. M. (2019). Assessing 'approaches to learning' in Botswana, Ghana and Kenya. Research in Comparative and International Education, 14(1), 118-140. https://doi. org/10.1177/1745499919829216

Ryan, R. M., \& Deci, E. L. (2020). Intrinsic and extrinsic motivation from a self-determination theory perspective: Definitions, theory, practices, and future directions. Contemporary Educational Psychology, 61, 101860. https:// doi.org/10.1016/j.cedpsych.2020.101860

Stokes, J. M., Yang, K., Swanson, K., Jin, W., Cubillos-Ruiz, A., Donghia, N. M., MacNair, C. R., French, S., Carfrae, L. A., Bloom-Ackermann, A., Tran, V. M., Chiappino-Pepe, A., Badran, A. H., Andrews, I. W., Chory, E. J., Church, G. M., Brown, E. D., Jaakkola, T. S., Barzilay, R., \& Collins, J. J. (2020). A deep learning approach to antibiotic discovery. Cell, 181(4), 688-702.

Tove, C., Nina, B. Ø., \& Tore, B. (2018). Approaches to studying: Associations with learning conceptions and preferences for teaching. Cogent Education, 5(1), 1480909. https://doi.org/10.1080/2331186X.2018.1480909

Turner, M., \& Baskerville, R. (2013). The experience of deep learning by accounting students. Accounting Education, 22(6), 582-604. https://doi.org/10.1080/09639284.2013.847323

Uiboleht, K., Karm, M., \& Postareff, L. (2018). The interplay between teachers' approaches to teaching, students' approaches to learning and learning outcomes: a qualitative multi-case study. Learning Environments Research, 
21(3), 321-347. https://ink.springer.com/article/10.1007/s10984-018-9257-1

University of Cape Coast. (2018). Professional Training Manual. Institute of Education, University of Cape Coast.

University of Oxford. (2017). Student Approaches to Learning, Paper 2. Institute for the Advancement of University Learning. https://www.learning.ox.ac.uk/support/teaching/resources

Venkatesan, L. (2015). An analysis of learning styles in nursing. Indian Journal of Advanced Nursing, 1(4), 19-23. https://www.researchgate.net/profile/Latha-Venkatesan-2/publication/338480314_Analysis_of_Learning_Style/ links/5e171564a6fdcc2837638a17/Analysis-of-Learning-Style.pdf

Wang, X. (2013). Why students choose STEM majors: Motivation, high school learning, and postsecondary context of support. American Educational Research Journal, 50(5), 1081-1121. https://www.jstor.org/stable/23526124

Yonker, J. E. (2011). The relationship of deep and surface study approaches on factual and applied test-bank multiplechoice question performance. Assessment \& Evaluation in Higher Education, 36(6), 673-686. https://doi.org/10.10 $80 / 02602938.2010 .481041$ 